\title{
Effects of time delay and body temperature on measurements of central venous oxygen saturation, venous-arterial blood carbon dioxide partial pressures difference, venous-arterial blood carbon dioxide partial pressures difference/arterial-venous oxygen difference ratio and lactate
}

Xiang-yu Wan ${ }^{1}$, Li-li Wei ${ }^{2}$, Yan Jiang ${ }^{3}$, Ping $\mathrm{Li}^{3}$ and Bo Yao ${ }^{1 *}$ (i)

\begin{abstract}
Background: Central venous oxygen saturation $\left(\mathrm{SCVO}_{2}\right)$, venous-arterial blood carbon dioxide partial pressures difference $\left(\mathrm{Pv}-\mathrm{aCO}_{2}\right)$, venous-arterial blood carbon dioxide partial pressures difference/arterial-venous oxygen difference ratio $\left(\mathrm{Pv}-\mathrm{aCO} \mathrm{CO}_{2} / \mathrm{Ca}_{-} \mathrm{VO}_{2}\right)$ and lactate are important parameters employed during shock resuscitation. We designed this study to confirm the effects of time delay and body temperature on measurements of these four parameters.

Methods: Arterial and central venous blood samples were simultaneously drawn by plastic syringes via indwelling intra-arterial and central venous catheters from critically ill patients. Blood gas analyses were performed on both samples and repeated after 10,20, 30,40, 50 and 60 min. Patients were divided into a control group and a high temperature group according to whether the body temperature was greater than $38^{\circ} \mathrm{C}$.
\end{abstract}

Results: A total of 30 critically ill patients were enrolled. There was a trend of increasing values for $\mathrm{ScvO}_{2}, \mathrm{Pv}-\mathrm{aCO}$, $\mathrm{Pv}-\mathrm{aCO} 2 / \mathrm{Ca}-\mathrm{vO}_{2}$ and lactate over time $(P<0.001)$. The $\mathrm{ScvO}_{2}$ differences were all lower in high temperature group after $10,20,30,40,50$ and 60 min when compared to the corresponding differences in the control group $(P<0.05)$. The differences in lactate values were slightly higher in the high temperature group, relative to the control group after 20, $30,40,50$ and 60 min $(P<0.05)$.

Conclusions: Measurements of $\mathrm{ScvO}_{2}, \mathrm{Pv}-\mathrm{aCO}$, lactate and $\mathrm{Pv}-\mathrm{aCO} / \mathrm{Ca}-\mathrm{vO}_{2}$ were affected by time delay or body temperature. We recommend that arterial and central venous blood gas samples be analyzed quickly within $10 \mathrm{~min}$, especially for patients with body temperature $<38^{\circ} \mathrm{C}$.

Trial registration: ChiCTR, ChiCTR1800014484. Registered 16 January 2018.

Keywords: $\mathrm{ScvO}_{2}, \mathrm{Pv}-\mathrm{aCO}$, Lactate, $\mathrm{Pv}-\mathrm{aCO} / \mathrm{Ca}-\mathrm{vO}_{2}$, Time delay, Body temperature

\footnotetext{
*Correspondence: icuyaobo@126.com

'Department of Critical Care Medicine, the Affiliated Hospital of Qingdao

University, Jiangsu Road 16, Qingdao 266000, China

Full list of author information is available at the end of the article
}

(c) The Author(s). 2018 Open Access This article is distributed under the terms of the Creative Commons Attribution 4.0 International License (http://creativecommons.org/licenses/by/4.0/), which permits unrestricted use, distribution, and reproduction in any medium, provided you give appropriate credit to the original author(s) and the source, provide a link to the Creative Commons license, and indicate if changes were made. The Creative Commons Public Domain Dedication waiver (http://creativecommons.org/publicdomain/zero/1.0/) applies to the data made available in this article, unless otherwise stated. 


\section{Background}

Early recognition and accurate correction of tissue hypoperfusion are important in the treatment of shock. Central venous oxygen saturation $\left(\mathrm{ScvO}_{2}\right)$, venous and arterial blood carbon dioxide partial pressure difference $\left(\mathrm{Pv}-\mathrm{aCO}_{2}\right)$, the venous-arterial blood carbon dioxide partial pressure difference/arterial-venous oxygen content difference ratio $\left(\mathrm{Pv}-\mathrm{aCO}_{2} / \mathrm{Ca}-\mathrm{vO}_{2}\right)$ and lactate are important parameters employed during shock resuscitation [1]. $\mathrm{ScvO}_{2}$ is associated with global tissue oxygenation, which can reflect the global balance between arterial $\mathrm{O}_{2}$ delivery and $\mathrm{O}_{2}$ consumption. If the value is low, anaerobic metabolism may arise. It was proved useful for hemodynamic management [2], and was recommended as one of the early resuscitation goals in 2012 sepsis guidelines [3]. Although $\mathrm{ScvO}_{2}$ was deleted in early resuscitation goals in 2016 sepsis guidelines [4], it is still a useful clinical parameter. A $\Delta \mathrm{ScvO}_{2}$ threshold value of $5.0 \%$ discriminated fluid responders from non-responders with a sensitivity of 0.78 and specificity of 0.95 [5]. Moreover, $\mathrm{ScvO}_{2}$ can also predict the success of spontaneous breathing trial [6]. $\mathrm{Pv}-\mathrm{aCO}_{2}$ is another alternative possible marker of tissue perfusion. According to the Fick equation, $\mathrm{Pv}-\mathrm{aCO}_{2}$ is inversely related to cardiac output [7]. A normal $\mathrm{Pv}-\mathrm{aCO}_{2}<5 \mathrm{mmHg}$ can be used as an adjunctive hemodynamic parameter to exclude tissue hypoperfusion in patients undergoing major surgery [8]. $\mathrm{Pv}-\mathrm{aCO}_{2}$ can also help clinicians make decisions of regarding the provision of therapy aimed at increasing cardiac output [7]. The $\mathrm{Pv}-\mathrm{aCO}_{2} / \mathrm{Ca}-\mathrm{vO}_{2}$ ratio was shown to be a good indicator of anerobiosis assessed by hyperlactatemia. Mekontso-Dessap A et al. found that the $\mathrm{Pv}$-aCO$/ 2 / \mathrm{Ca}-\mathrm{vO}_{2}$ ratio (cut-off value $\geq 1.6$ ) can detect global anaerobic metabolism in critically ill patients [9]. The $\mathrm{Pv}-\mathrm{aCO}_{2} / \mathrm{Ca}-\mathrm{vO}_{2}$ ratio may provide useful information for assessing the lactate clearance potential and optimizing the lactate clearance rate [10]. Moreover, the $\mathrm{Pv}-\mathrm{aCO} / \mathrm{Ca}-\mathrm{vO}_{2}$ ratio (cut-off value $\geq 1.6$ ) was an independent predictor of ICU mortality in septic shock patients with high $\mathrm{ScvO}_{2}$ after resuscitation [11]. Increased serum lactate is an early indicator of septic shock and helps accomplish resuscitation goal, and it is recommended utilizing in sepsis guidelines [3, 4]. Given these four parameters above, and their values in shock resuscitation, some researchers have compiled them into a flow sheet to guide resuscitation therapy in septic shock [1].

Before using a clinical parameter in therapeutic decisions, its accuracy is important. Unfortunately, previous studies have found that the values of arterial oxygen partial pressure $\left(\mathrm{PaO}_{2}\right)$ and arterial carbon dioxide partial pressure $\left(\mathrm{PaCO}_{2}\right)$ were influenced by time delay and sample storage temperature in blood gas analysis $[12,13]$. The effects of time delay and body temperature on the measurements of $\mathrm{ScvO}_{2}, \mathrm{Pv}_{\mathrm{aCO}}$, lactate and $\mathrm{Pv}-\mathrm{aCO} / \mathrm{Ca}-\mathrm{vO}_{2}$ have not been adequately studied. Thus, we designed this study to confirm the effects of time delay and body temperature on these four specific parameters.

\section{Methods}

The study was approved by the Ethics Committee of our hospital and registered at Chinese clinical trial registry (ChiCTR1800014484). It was performed from January 2018 to May 2018 in the intensive care unit of the affiliated hospital of Qingdao university. The patients with indwelling central venous and intra-arterial catheters were enrolled. Therefore, no additional invasive procedures were performed on patients merely to collect blood samples. Patients treated with antipyretic drugs or physical cooling were excluded.

A $2 \mathrm{~mL}$ sample of arterial blood was drawn from the indwelling intra-arterial catheter, and simultaneously, 2 $\mathrm{mL}$ venous blood sample was collected from the central venous catheter using plastic blood gas syringes (BD Preset $^{\mathrm{T}} 3 \mathrm{ml}, 22 \mathrm{G} \times 1^{\prime \prime}$, Becton, Dickinson and Company, United Kingdom) by a nurse. The nurse repeatedly drew blood in this manner for a total of 7 times, producing 7 sets of central venous and arterial blood samples simultaneously. Blood gas analysis was performed on one of the sets of the venous and arterial samples via blood gas analyzer (Radiometer ABL90 FLEX, Denmark) as soon as possible after sampling by another nurse. The time needed for transporting samples to the blood gas analyzer was less than $2 \mathrm{~min}$ for the first analysis. Then, blood gas analyses were repeated at 10, 20, 30, 40, 50 and $60 \mathrm{~min}$ after drawing for remaining 6 sets of samples. During the time delay, the blood samples were stored at $22{ }^{\circ} \mathrm{C}$ (room temperature). $\mathrm{Pv}^{-a C O} \mathrm{CO}_{2}$ and the $\mathrm{Pv}-\mathrm{aCO} / \mathrm{Ca}-\mathrm{vO}_{2}$ ratio were calculated [11].

The patients' baseline data were also collected, such as age, gender, Acute Physiology and Chronic Health Evaluation (APACHE) II scores and primary diseases. Patients were divided into either the control group or the high temperature group according to whether their body temperature was greater than $38^{\circ} \mathrm{C}$. Body peripheral temperature was measured by mercury thermometer in axilla. Drawing blood gas samples and measuring body temperature were performed simultaneously.

\section{Statistics analysis}

The statistical analysis was performed using SPSS 22.0 software (SPSS, Inc., Chicago, IL, USA). The results were expressed as mean \pm SD. Statistical analysis of the parameters over time was analyzed by repeated-measures ANOVA (analysis of variance). The statistical significance was set at $P<0.05$. 


\section{Results}

A total of 30 critically ill patients were enrolled. The baseline characteristics of them are shown in Tables 1 and 2. There were no significant differences in baseline data between two groups $(P>0.05)$.

There was a trend of increasing values for $\mathrm{ScvO}_{2}$, $\mathrm{Pv}-\mathrm{aCO}_{2}, \mathrm{Pv}-\mathrm{aCO}_{2} / \mathrm{Ca}-\mathrm{vO}_{2}$ and lactate over time $(P<$ 0.001). $\mathrm{ScvO}_{2}, \mathrm{Pv}-\mathrm{aCO} \mathrm{CO}_{2} / \mathrm{Ca}-\mathrm{vO}_{2}$ and lactate values of the samples stored for 10, 20, 30, 40, 50 and $60 \mathrm{~min}$ were significantly higher relative to baseline $(P<0.05)$. There were no significant differences of $\mathrm{PaCO}_{2}$ and $\mathrm{PvCO}_{2}$ value over time $(P>0.05)$. The values for $\mathrm{Pv}_{\mathrm{aCO}}$ only increased after 40, 50 and 60 min compared to baseline $(P<0.05)$, but there were no significant differences after 10, 20 or $30 \mathrm{~min}$ (Table 3 ).

There was a trend of increasing $\mathrm{ScvO}_{2}$ differences, $\mathrm{Pv}-\mathrm{aCO}_{2}$ differences, $\mathrm{Pv}-\mathrm{aCO}_{2} / \mathrm{Ca}-\mathrm{vO}_{2}$ differences and lactate differences between baseline and some point along storage time $(P<0.05)$. The $\mathrm{ScvO}_{2}$ differences between baseline and after 10, 20, 30, 40, 50 and 60 min were all lower in the high temperature group than differences in the control group $(P<0.05)$. The lactate differences between baseline and 20,30, 40, 50 and $60 \mathrm{~min}$ were all slightly higher in the high temperature group than the differences in the control group $(\mathrm{P}<0.05)$. $\mathrm{Pv}-\mathrm{aCO}_{2} / \mathrm{Ca}-\mathrm{vO}_{2}$ ratio differences between baseline and $10 \mathrm{~min}$ were lower in the high temperature group than the ratio differences in the control group $(P<0.05)$ (Table 4$)$.

\section{Discussion}

In this study, we found that there was a trend of increasing values for $\mathrm{ScvO}_{2}, \mathrm{Pv}-\mathrm{aCO}, \mathrm{Pv}-\mathrm{aCO}_{2} / \mathrm{Ca}-\mathrm{vO}_{2}$ and lactate values with increased storage time. The differences in $\mathrm{ScvO}_{2}, \mathrm{Pv}-\mathrm{aCO}_{2} / \mathrm{Ca}-\mathrm{vO}_{2}$ and lactate between certain periods of storage time and baseline demonstrated differences between the high temperature group and the control group along certain points of storage time.

Table 1 Baseline characteristics of patients

\begin{tabular}{ll}
\hline Variables & Value \\
\hline Age (years) & $63 \pm 16$ \\
Gender (male/female) & $19 / 11$ \\
APACHE II scores & $21 \pm 5$ \\
Hemoglobin (g/L) & $96.3 \pm 26.4$ \\
White blood cells (10 $/$ L) & $15.7 \pm 11.2$ \\
Primary diseases & \\
Pneumonia & 12 \\
Abdominal infection & 8 \\
$\quad$ Gastrointestinal hemorrhage & 5 \\
Heart failure & 4 \\
Bacterial liver abscess & 1 \\
\hline
\end{tabular}

Table 2 Baseline characteristics of two groups

\begin{tabular}{|c|c|c|c|}
\hline Variables & $\begin{array}{l}\text { Control group } \\
(n=19)\end{array}$ & $\begin{array}{l}\text { High temperature } \\
\text { group }(n=11)\end{array}$ & $P$ value \\
\hline Age (years) & $62 \pm 17$ & $65 \pm 13$ & 0.704 \\
\hline Gender (male/female) & $11 / 8$ & $8 / 3$ & 0.466 \\
\hline APACHE II scores & $21 \pm 6$ & $20 \pm 5$ & 0.770 \\
\hline Hemoglobin (g/L) & $91.9 \pm 19.2$ & $103.9 \pm 35.5$ & 0.320 \\
\hline White blood cells $\left(10^{9} / \mathrm{L}\right)$ & $14.9 \pm 8.5$ & $17.2 \pm 15.1$ & 0.597 \\
\hline $\begin{array}{l}\text { Catecholamine } \\
\text { therapy (yes/no) }\end{array}$ & $11 / 8$ & $6 / 5$ & 0.858 \\
\hline Sepsis (yes/no) & $9 / 10$ & $7 / 4$ & 0.389 \\
\hline Surgery (yes/no) & $10 / 9$ & $4 / 7$ & 0.389 \\
\hline Trauma (yes/no) & $1 / 18$ & $0 / 11$ & 1.000 \\
\hline $\mathrm{PO}_{2}$ baseline $(\mathrm{mmHg})$ & $123 \pm 106$ & $107 \pm 34$ & 0.551 \\
\hline $\mathrm{ScvO}_{2}$ baseline $(\mathrm{mmHg})$ & $67.7 \pm 9.4$ & $72.8 \pm 7.7$ & 0.140 \\
\hline $\begin{array}{l}\text { Patmospheric- } \mathrm{vO}_{2} \\
\text { baseline }(\mathrm{mmHg})\end{array}$ & $122.2 \pm 5.9$ & $111.9 \pm 5.8$ & 0.084 \\
\hline $\mathrm{PvCO}_{2}$ baseline $(\mathrm{mmHg})$ & $47.7 \pm 11.2$ & $45.2 \pm 11.3$ & 0.413 \\
\hline $\mathrm{PaCO}_{2}$ baseline $(\mathrm{mmHg})$ & $42.6 \pm 12.1$ & $39.1 \pm 10.1$ & 0.435 \\
\hline $\mathrm{Pv}-\mathrm{aCO}_{2}$ baseline $(\mathrm{mmHg})$ & $6.1 \pm 2.5$ & $6.0 \pm 2.4$ & 0.920 \\
\hline $\mathrm{Pv}-\mathrm{aCO} / \mathrm{Ca}-\mathrm{vO}_{2}$ baseline & $1.7 \pm 0.6$ & $1.8 \pm 0.5$ & 0.626 \\
\hline Lactate $(\mathrm{mmol} / \mathrm{L})$ & $1.4 \pm 0.8$ & $2.4 \pm 2.1$ & 0.149 \\
\hline
\end{tabular}

According to this study, we often over-estimated $\mathrm{SvO}_{2}$ levels of the central venous blood samples. The guideline of the American Association for Respiratory Care states that a delay in analysis of a venous blood gas of $30 \mathrm{~min}$ is acceptable [14]. After a $30 \mathrm{~min}$ time delay in analysis, the $\mathrm{ScvO}_{2}$ increased approximately $6 \%$ in our study. This indicated that the guideline may lead to unsafe practices. The $\mathrm{ScvO}_{2}$ value was increasing over all storage times in the study, so we recommend blood gas samples be analyzed as soon as possible. It was proven that the $\mathrm{PO}_{2}$ of blood stored in a glass syringe decreases slightly over time, primarily as a result of continuing cellular metabolism [13]. However, plastic syringes have supplanted glass syringes because of their convenience, low cost and breakage resistance. But plastic syringes, unlike glass syringes, are permeable to $\mathrm{O}_{2}$ [15]. Atmospheric $\mathrm{O}_{2}$ has a partial pressure of $159 \mathrm{mmHg}$, well above venous blood $\mathrm{O}_{2}$. Therefore, $\mathrm{O}_{2}$ will permeate into plastic syringes until there is $\mathrm{O}_{2}$ partial pressure equilibration between the blood sample and the atmosphere. A previous study also indicated that the $\mathrm{ScvO}_{2}$ value increased over storage time [16]. In this study, we found that the rate of $\mathrm{ScvO}_{2}$ change in patients with a temperature $\geq 38$ ${ }^{\circ} \mathrm{C}$ was lower than patients with temperature $<38{ }^{\circ} \mathrm{C}$. The baseline $\mathrm{ScvO}_{2}$ values and atmospheric-venous 
Table 3 Changes in values at different time points

\begin{tabular}{|c|c|c|c|c|c|c|c|}
\hline Variables & Baseline & $10 \mathrm{~min}$ & $20 \mathrm{~min}$ & $30 \mathrm{~min}$ & $40 \mathrm{~min}$ & $50 \mathrm{~min}$ & $60 \mathrm{~min}$ \\
\hline $\mathrm{ScvO}_{2}(\%)$ & $69.6 \pm 9.0$ & $71.8 \pm 8.3^{*}$ & $73.8 \pm 8.3^{*}$ & $75.9 \pm 8.0^{*}$ & $77.5 \pm 7.8^{*}$ & $79.6 \pm 8.1^{*}$ & $81.7 \pm 7.5^{*}$ \\
\hline $\mathrm{PaCO}_{2}(\mathrm{mmHg})$ & $41.4 \pm 11.4$ & $41.7 \pm 11.3$ & $42.2 \pm 11.4$ & $42.5 \pm 11.4$ & $42.9 \pm 11.3$ & $43.2 \pm 11.2$ & $43.6 \pm 11.1$ \\
\hline $\mathrm{PvCO}_{2}(\mathrm{mmHg})$ & $47.4 \pm 11.2$ & $47.8 \pm 10.9$ & $48.3 \pm 10.7$ & $48.9 \pm 10.7$ & $49.4 \pm 10.9$ & $49.9 \pm 10.7$ & $50.3 \pm 10.5$ \\
\hline $\mathrm{Pv}-\mathrm{aCO}{ }_{2}(\mathrm{mmHg})$ & $6.1 \pm 2.4$ & $6.1 \pm 2.5$ & $6.1 \pm 2.5$ & $6.3 \pm 2.5$ & $6.6 \pm 2.6^{*}$ & $6.7 \pm 2.8^{*}$ & $6.7 \pm 2.9^{*}$ \\
\hline $\mathrm{PV}-\mathrm{aCO} \mathrm{CO}_{2} / \mathrm{Ca}-\mathrm{vO}_{2}$ & $1.7 \pm 0.6$ & $1.9 \pm 0.6^{*}$ & $2.1 \pm 0.8^{*}$ & $2.6 \pm 1.6^{*}$ & $3.0 \pm 1.9^{*}$ & $3.3 \pm 2.2^{*}$ & $4.0 \pm 3.5^{*}$ \\
\hline Lactate $(\mathrm{mmol} / \mathrm{L})$ & $1.8 \pm 1.5$ & $1.9 \pm 1.5^{*}$ & $2.1 \pm 1.5^{*}$ & $2.2 \pm 1.5^{*}$ & $2.3 \pm 1.5^{*}$ & $2.4 \pm 1.6^{*}$ & $2.6 \pm 1.6^{*}$ \\
\hline
\end{tabular}

${ }^{*}$ significant difference compared to baseline $(P<0.05)$

blood $\mathrm{O}_{2}$ partial pressure difference between two groups displayed no difference. Therefore, the increasing $\mathrm{O}_{2}$ consumption may be explained the effects of temperature on $\mathrm{ScvO}_{2}$. We speculated that blood cells have an intrinsically hypermetabolic state in febrile patients and subsequently consumed more $\mathrm{O}_{2}$. Lactate is one of metabolites. The faster rising lactate in the high temperature group of this study may support the idea that blood cells in febrile patients had a high hypermetabolic state. Advanced cell experiments were needed to confirm the hypothesis. In previous studies, temperature correction of blood gas samples is not recommended [14, 17]. But according to our results, the effect of temperature on $\mathrm{ScvO}_{2}$ should not be ignored.

There were no significant differences of $\mathrm{PaCO}_{2}$ and $\mathrm{PvCO}_{2}$ value over time. The $\mathrm{Pv}-\mathrm{aCO}_{2}$ increased only approximately $0.2 \mathrm{mmHg}$ after a $30 \mathrm{~min}$ time delay in analysis, which may not have very important clinical implications. Furthermore, no effect of temperature on $\mathrm{Pv}-\mathrm{aCO}$ was found. So there were few clinical effects of time delay and temperature on $\mathrm{Pv}-\mathrm{aCO}_{2}$ value. In the calculation of $\mathrm{Pv}-\mathrm{aCO}_{2} /$ $\mathrm{Ca}-\mathrm{vO}_{2}$ [11], $\mathrm{O}_{2}$ partial pressure is an important parameter. Because of effects of the time delay on blood $\mathrm{O}_{2}$ partial pressure [12, 13], $\mathrm{Pv}-\mathrm{aCO}_{2} / \mathrm{Ca}-\mathrm{vO}_{2}$ may also be affected by time delay. In actuality, our results proved that this is the case. After a $30 \mathrm{~min}$ time delay, the ratio increased 1 by almost. Further, $\mathrm{Pv}-\mathrm{aCO} / \mathrm{Ca}-\mathrm{vO}_{2}$ difference was lower in patients in the high temperature group. At $10 \mathrm{~min}$, the value demonstrated a significant difference. Lactate values were also affected by time delay and temperature, but the influence was not very strong. After a 30

Table 4 Comparisons of values between two groups

\begin{tabular}{|c|c|c|c|c|c|c|}
\hline Groups & $10 \mathrm{~min}$ & $20 \mathrm{~min}$ & $30 \mathrm{~min}$ & $40 \mathrm{~min}$ & $50 \mathrm{~min}$ & $60 \mathrm{~min}$ \\
\hline \multicolumn{7}{|l|}{$\Delta \mathrm{ScvO}_{2}$} \\
\hline Control group $(n=19)$ & $2.8 \pm 1.5$ & $4.9 \pm 1.6$ & $7.2 \pm 2.7$ & $9.1 \pm 3.2$ & $11.4 \pm 3.5$ & $14.0 \pm 4.4$ \\
\hline High temperature group $(n=11)$ & $1.4 \pm 0.9$ & $3.2 \pm 1.7$ & $4.9 \pm 1.8$ & $6.1 \pm 2.5$ & $7.5 \pm 3.4$ & $8.9 \pm 4.3$ \\
\hline$P$ value & 0.013 & 0.014 & 0.016 & 0.011 & 0.006 & 0.005 \\
\hline \multicolumn{7}{|l|}{$\triangle \mathrm{PV}-\mathrm{aCO}{ }_{2}$} \\
\hline Control group $(n=19)$ & $0.1 \pm 0.6$ & $0.1 \pm 1.0$ & $0.3 \pm 1.0$ & $0.7 \pm 0.8$ & $0.7 \pm 0.9$ & $0.8 \pm 1.1$ \\
\hline High temperature group $(n=11)$ & $-0.2 \pm 0.4$ & $-0.2 \pm 0.9$ & $0.2 \pm 0.8$ & $0.1 \pm 1.0$ & $0.4 \pm 1.2$ & $0.4 \pm 1.4$ \\
\hline$P$ value & 0.138 & 0.469 & 0.668 & 0.054 & 0.437 & 0.313 \\
\hline \multicolumn{7}{|l|}{$\triangle \mathrm{Pv}-\mathrm{aCO} \mathrm{CO}_{2} / \mathrm{Ca}-\mathrm{vO}_{2}$} \\
\hline Control group $(n=19)$ & $0.23 \pm 0.17$ & $0.46 \pm 0.49$ & $1.1 \pm 1.7$ & $1.51 \pm 1.94$ & $1.89 \pm 2.13$ & $2.79 \pm 3.85$ \\
\hline High temperature group $(n=11)$ & $0.04 \pm 0.16$ & $0.25 \pm 0.39$ & $0.59 \pm 0.63$ & $0.77 \pm 1.04$ & $1.10 \pm 1.30$ & $1.41 \pm 1.46$ \\
\hline$P$ value & 0.005 & 0.252 & 0.374 & 0.253 & 0.279 & 0.264 \\
\hline \multicolumn{7}{|l|}{$\Delta$ Lactate } \\
\hline Control group $(n=19)$ & $0.13 \pm 0.08$ & $0.23 \pm 0.10$ & $0.33 \pm 0.12$ & $0.43 \pm 0.18$ & $0.51 \pm 0.19$ & $0.62 \pm 0.22$ \\
\hline High temperature group $(n=11)$ & $0.16 \pm 0.08$ & $0.35 \pm 0.14$ & $0.51 \pm 0.31$ & $0.72 \pm 0.44$ & $0.89 \pm 0.62$ & $1.14 \pm 0.80$ \\
\hline$P$ value & 0.309 & 0.012 & 0.030 & 0.015 & 0.016 & 0.012 \\
\hline
\end{tabular}

$\triangle \mathrm{ScVO}_{2} \times \min \mathrm{ScVO}_{2} \times$ min- $\mathrm{ScvO}_{2}$ baseline

$\triangle P v-a C_{2} \times \operatorname{min~} \mathrm{Pv}-\mathrm{aCO}_{2} \times$ min- $\mathrm{Pv}-\mathrm{aCO}_{2}$ baseline

$\triangle \mathrm{Pv}^{-a C O} / \mathrm{Ca}-\mathrm{vO}_{2} \times \min \mathrm{Pv}-\mathrm{aCO} / / \mathrm{Ca}-\mathrm{vO}_{2} \times$ min- $\mathrm{Pv}-\mathrm{aCO} / \mathrm{Ca}-\mathrm{vO}_{2}$ baseline

$\Delta$ Lactate $x$ min Lactate $x$ min- Lactate baseline 
min time delay, the lactate increased only approximately $0.4 \mathrm{mmol} / \mathrm{L}$.

\section{Conclusions}

There were some influences of time delay or body temperature on $\mathrm{ScvO}_{2}, \mathrm{Pv}_{\mathrm{a}} \mathrm{aCO}$, lactate and $\mathrm{Pv}-\mathrm{aCO} /$ $\mathrm{Ca}-\mathrm{vO}_{2}$ values. We recommend that arterial and central venous blood gas samples be analyzed quickly within 10 min, especially for patients with body temperature $<38^{\circ} \mathrm{C}$.

\begin{abstract}
Abbreviations
APACHE: Acute Physiology and Chronic Health Evaluation; Lac: Lactate; $\mathrm{PaCO}_{2}$ : Arterial carbon dioxide partial pressure; $\mathrm{PaO}_{2}$ : Arterial oxygen partial pressure; $\mathrm{PV}-\mathrm{aCO}_{2}$ : Venous and arterial blood carbon dioxide partial pressures difference; $\mathrm{Pv}-\mathrm{aCO} \mathrm{CO}_{2} / \mathrm{Ca}_{\mathrm{V}} \mathrm{O}_{2}$ : Venous and arterial blood carbon dioxide partial pressures difference/arterial-venous oxygen difference ratio; $\mathrm{ScvO}_{2}$ : Central venous oxygen saturation
\end{abstract}

\section{Acknowledgements \\ Not applicable}

\section{Funding}

Not applicable

\section{Availability of data and materials}

The datasets during the current study available from the corresponding author on reasonable request.

\section{Authors' contributions}

BY designed the study and modified the manuscript. XW participated in the design of the study, performed the statistical analysis and drafted the manuscript. XW, LW, YJ and PL performed the study and collected data. All authors read and approved the final manuscript.

\section{Ethics approval and consent to participate}

This study was approved by the affiliated hospital of Qingdao university ethics committee and registered at Chinese clinical trial registry (ChiCTR1800014484). The written informed consent was obtained from the next of kin of the patients before their enrollment.

\section{Consent for publication}

Not applicable

\section{Competing interests}

The authors declare that they have no competing interests.

\section{Publisher's Note}

Springer Nature remains neutral with regard to jurisdictional claims in published maps and institutional affiliations.

\section{Author details}

${ }^{1}$ Department of Critical Care Medicine, the Affiliated Hospital of Qingdao University, Jiangsu Road 16, Qingdao 266000, China. ²Department of Nursing, the Affiliated Hospital of Qingdao University, Jiangsu Road 16, Qingdao 266000, China. ${ }^{3}$ Department of Critical Care Medicine, the Affiliated Hospital of Qingdao University, Haier Road 16, Qingdao 266000, China.

Received: 3 August 2018 Accepted: 29 November 2018 Published online: 11 December 2018

\section{References}

1. Mallat J, M L, Tronchon L, Vallet B, Thevenin D. Use of venous-to-arterial carbon dioxide tension difference to guide resuscitation therapy in septic shock. World J Crit Care Med. 2016:5(1):47-56. https://doi.org/10.5492/wjccm.v5.i1.47.

2. Mikor A, Trásy D, Németh MF, Osztroluczki A, Kocsi S, Kovács I, et al. Continuous central venous oxygen saturation assisted intraoperative hemodynamic management during major abdominal surgery: a randomized, controlled trial. BMC Anesthesiol. 2015;15:82. https://doi.org/10. 1186/s12871-015-0064-2.

3. Dellinger RP, Levy MM, Rhodes A, Annane D, Gerlach H, Opal SM, et al. Surviving Sepsis campaign: international guidelines for management of severe sepsis and septic shock, 2012. Intensive Care Med. 2013;39(2):165-228. https://doi.org/10.1007/s00134-012-2769-8.

4. Rhodes A, Evans LE, Alhazzani W, Levy MM, Antonelli M, Ferrer R, et al. Surviving Sepsis Campaign: International Guidelines for Management of Sepsis and Septic Shock: 2016. Crit Care Med. 2017:45(3):486-552.

5. Xu B, Yang X, Wang C, Jiang W, Weng L, Hu X, Peng J, Du B. Changes of central venous oxygen saturation define fluid responsiveness in patients with septic shock: a prospective observational study. J Crit Care. 2017;38:13-9. https://doi.org/10.1016/j.jcrc.2016.09.030.

6. Georgakas I, Boutou AK, Pitsiou G, Kioumis I, Bitzani M, Matei K, Argyropoulou P, Stanopoulos I. Central venous oxygen saturation as a predictor of a successful spontaneous breathing trial from mechanical ventilation: a prospective, nested case-control study. Open Respir Med J. 2018;12:11-20. https://doi.org/10.2174/1874306401812010011.

7. Lamia B, Monnet X, Teboul JL. Meaning of arterio-venous PCO2 difference in circulatory shock. Minerva Anestesiol. 2006;72(6):597-604.

8. Silbert BI, Litton E, Ho KM. Central venous-to-arterial carbon dioxide gradient as a marker of occult tissue hypoperfusion after major surgery. Anaesth Intensive Care. 2015;43(5):628-34

9. Mekontso-Dessap A, Castelain V, Anguel N, Bahloul M, Schauvliege F Richard C, Teboul JL. Combination of venoarterial PCO2 difference with arteriovenous $\mathrm{O} 2$ content difference to detect anaerobic metabolism in patients. Intensive Care Med. 2002;28(3):272-7.

10. He HW, Liu DW, Long Y, Wang XT. High central venous-to-arterial CO2 difference/arterial-central venous $\mathrm{O} 2$ difference ratio is associated with poor lactate clearance in septic patients after resuscitation. J Crit Care. 2016:31(1): 76-81. https://doi.org/10.1016/j.jcrc.2015.10.017.

11. He H, Long Y, Liu D, Wang X, Tang B. The Prognostic Value of Central Venous-to-Arterial CO2 Difference/Arterial-Central Venous O2 Difference Ratio in Septic Shock Patients with Central Venous O2 Saturation $\geq 80$. Shock. 2017:48(5):551-7. https://doi.org/10.1097/SHK.0000000000000893.

12. Mohammadhoseini E, Safavi E, Seifi S, Seifirad S, Firoozbakhsh S, Peiman S. Effect of sample storage temperature and time delay on blood gases, bicarbonate and $\mathrm{pH}$ in human arterial blood samples. Iran Red Crescent Med J. 2015;17(3):e13577. https://doi.org/10.5812/ircmj.13577.

13. Srisan $P$, Udomsri $T$, Jetanachai $P$, Lochindarat $S$, Kanjanapattanakul W. Effects of temperature and time delay on arterial blood gas and electrolyte measurements. J Med Assoc Thail. 2011;94(Suppl 3):S9-14.

14. Davis MD, Walsh BK, Sittig SE, Restrepo RD. AARC clinical practice guideline: blood gas analysis and hemoximetry: 2013. Respir Care. 2013;58(10):1694703. https://doi.org/10.4187/respcare.02786.

15. Ruppel GL. Of time and temperature, plastic and glass: specimen handling in the blood-gas laboratory. Respir Care. 2006;51(7):717-8.

16. Ghanpur R, Santamaria J, Dixon B. Plastic blood gas syringes and measurement error in central venous oxygen saturations. Shock. 2016;46(3): 287-9. https://doi.org/10.1097/SHK.0000000000000622.

17. Shapiro BA. Temperature correction of blood gas values. Respir Care Clin N Am. 1995;1(1):69-76.

Ready to submit your research? Choose BMC and benefit from:

- fast, convenient online submission

- thorough peer review by experienced researchers in your field

- rapid publication on acceptance

- support for research data, including large and complex data types

- gold Open Access which fosters wider collaboration and increased citations

- maximum visibility for your research: over $100 \mathrm{M}$ website views per year

At $\mathrm{BMC}$, research is always in progress.

Learn more biomedcentral.com/submission 